\title{
WHAT GETS INSIDE: Violent Entanglements and Toxic Boundaries in Mexico City
}

\author{
ELIZABETH F. S. ROBERTS \\ University of Michigan \\ (D) http:/ / orcid.org/0000-0003-1025-1236
}

In Colonia Periférico, a working-class neighborhood of mala fama (bad reputation) in Mexico City, my landlady Señora Natividad always jokes about the smell. The joke comes in her knickknack-filled kitchen where she feeds children, grandchildren, great-grandchildren, other relatives, and boarders like me, scolding us to eat more mole and drink more soda. She tells us how she once visited her son for a few weeks outside of Portland, Oregon. It was beautiful and very green, and the houses were very big. But Señora Nati wanted to be back in Colonia Periférico. In Portland, she was alone in the house and the streets were empty, an alienating experience for Nati, who was accustomed to a dense neighborhood in which every family had arrived in the same land invasion more than fifty years ago. The isolation was not for her. And then, always, the punch line: "I needed to be back here where the air is sweet." Or sometimes she says, "I needed to be back here, where we get the stink for free." We laugh loudly either way, because in Colonia Periférico, the air is shit.

Señora Nati's sturdy, narrow, four-story house, painted a rich aquamarine and sandwiched between similarly vertical houses, is perched on top of a ravine holding a narrow stream of dam runoff, filled with aguas negras (untreated sewage) and garbage. Birds, rats, and dogs frolic in the brush entangled with garbage on 
the riverbank below. In most rainy seasons the dam overflows and the ravine fills, flooding these houses with torrential brown waters roiled with debris. I learned from local urban water ecologists that this flooding fills the walls of cement houses like Señora Nati's with salmonella, E. coli, and fecal enterococcus. Some in Colonia Periférico blame the dam for the respiratory diseases that plague the residents. It's hard to say if there is a higher incidence of respiratory problems in Colonia Periférico than elsewhere in this chronically polluted city.

But the stench is distinctive. Every time I return to Colonia Periférico after even a few days away, I have to brace myself all over again for the nasal assault. In a few hours I get used to it, though, and can even sleep. Señora Nati missed it when she was away. The smell does double duty in making this distinct place. Besides providing an aromatic signature, the dam, along with other noxious attributes - like the cement factories that surround Colonia Periférico, filling its boundary airs with dust - provides protection. The dam and the cement factories are just a few of Colonia Periférico's miasmatic membranes, which manage what gets inside the neighborhood. They prevent the incursion of police and public health workers, whose presence has intensified since the passage of the North American Free Trade Agreement (NAFTA; 1994) and the declaration of the War on Drugs (2006).

My work in Mexico City involves collaboration with public health and environmental health scientists from the United States, Mexico, and Canada who have been studying the developmental effects of chemical exposures over the life course through a birth-cohort study of about nine hundred matched mother-child pairs recruited from throughout Mexico City (Roberts 2015a; Roberts and Sanz, forthcoming). My ethnographic work focuses on six of the study participant families, who are located in two working-class neighborhoods, Colonia Periférico and Buena Vista. ${ }^{1}$ The environmental health scientists increasingly make connections between nutrition, chemical exposure, and body mass. This is especially apt for a study in Mexico, a country since 2013 designated by the World Health Organization (WHO) as the world's fattest industrial nation, and one in which fat is intensively classed (Roberts 2015b).

In discussing the children who have grown up over the course of the study, the environmental health scientists I work with often invoke the concept of resilience. In early 2016 a team member, Dr. Arias, said to me, "What we're finding is that some kids are resilient. It's like they don't somatize what they are living. They don't get it through their body." Comments about the impermeability of some children's bodies emerge from efforts across public health and the life 
sciences to find mechanisms for creating individually resilient kids. Impermeability to surroundings should stabilize children in the face of unstable realities. This notion of bounded resilience unnerves me. It does nothing to change structural inequalities and naturalizes certain groups as able to endure more. The individualized focus on preventing what kids "are living" from getting inside can feel pragmatic, though, given that Mexico's current reality makes imagining largescale change impossible. But I don't want that to be true.

\section{BOUNDARIES AND ENTANGLEMENTS}

In this article I am interested in how Señora Nati, a rural-to-urban migrantcolonist in Mexico City, and Dr. Arias, a U.S.-based health researcher, both experience what-gets-inside as crucial to what shapes life conditions for themselves and others. Neither of them is celebrating the postmodern collapse of distinctions between inside and out, or arguing that insides are always already outsides, or vice versa. Thinking with Señora Nati and Dr. Arias, I seek to examine how maintaining an inside and managing what enters it constitutes a crucial survival response within the continued violent capitalist interpenetration of all the earth's biota. Dr. Arias and Señora Nati possess different means to manage problematic interpenetration. Dr. Arias seeks the impermeability of a resilient, sovereign, bounded individual, preventing the world from getting inside. Instead of prevention, Señora Nati assumes that survival depends on the management of what gets inside and what does not. By asserting boundaries, both approaches complicate the social sciences' recent embrace of entanglement.

Entanglement allows us to understand how outsides and insides are constantly co-constituted across different lifeworlds, and the concept could easily be put to work for understanding what-gets-inside in Mexico City. In fact, entanglement was my entrée for collaboration with these environmental health scientists and participant families. I wanted to study the entanglement of the production of scientific knowledge about chemical exposure in Mexico City and the daily lives of study participant families in Mexico City. My goal has been to develop a bioethnographic research platform that combines ethnographic data with the biological data collected from these families for more than two decades, to ask questions about the relationship of environment to health that would not be possible through ethnographic or biological data alone (Roberts and Sanz, forthcoming). The bulk of my time these days is spent trying to make bioethnography happen, which means actively working with environmental health scientists as 
they disentangle phenomena by breaking them into variables that can be arranged linearly to make numbers.

This is not what I set out to do when I proposed bioethnography as a means to entangle phenomena. Like many scholars working within medical anthropology and science and technology studies (STS), I seek to trace the contingent and uncertain entangled relations that endow objects with seemingly stable and linear boundaries. Entanglement assumes relational beingness, permitting us to see how linear boundaries restrict our ability to know the world better (Barad 2007; Rozental 2016; Tosoni and Pinch 2016). However, despite my own continued participation in entanglement, life conditions in Colonia Periférico-where breathing shit offers protection against security and health officials in contemporary Mexico - make me increasingly uneasy about the deployment of entanglement and the embrace of its close relations, "uncertainty" (Sanabria and YatesDoerr 2015) and "staying with the trouble" (Haraway 2016). So, while investigating the implications of how allowing and even welcoming noxious permeability provides a boundary that prevents other penetrations like police violence, I am not celebrating the endless entanglement of those who can live within the shit.

Let's review what entanglement rejects. Historians and philosophers of science provide a history of how bounded facts came to be made through a world divided between subject and objects. Autonomous rational individuals, numbers, genes, calories, neurons, and bacteria came into being as apolitical entities that stood on their own, to be seen by anyone, through what Lorraine Daston (1992, 599) calls "mechanical objectivity" (see also Winner 1980). These objects can be without being related, to misquote Annemarie Mol (2002). This is the logic of industrial modernism, an autonomous mode of existence that divorced objects from their surroundings and helped produce the mess we are in, a mode in which, for instance, chemicals or antibiotics are imagined not to affect the world beyond their designated purpose and genes unaffected by the world around them are imagined to be the central means to understand the phenotype and behavior of organismal beingness (Keller 2000).

In the past decade or so, many of the social sciences have noted a move away from this mode of existence toward entanglement, in which, now to quote Mol $(2002,54)$ correctly, "to be is to be related." You think there is such a thing as a gene that we can isolate? Well, think again. A gene is a relationship, and that relationship is political. You think genes determine beingness? Well, think again. Epigenetics demonstrates that gene expression is enacted through the environment 
of the organism. You think a fact, a number, or a piece of evidence can stand alone, can be a thing in itself? Well, think again. All of the entities that looked bounded through those misguided modernist lenses are embedded in a myriad of relations and, in fact, do not exist without them. This must be the way to live in mutuality with each other on and with this planet: tracing out and acknowledging the messy and entangled relations that produce existence. But the fact that certain groups of people are and have always been entangled in shit makes me wonder about entanglement. What does an entangled prescription for being in the world do for or with those who have always had to stay with the trouble?

In my effort here to examine what-gets-inside in Colonia Periférico, and to reflect critically on entanglement, I am indebted to scholars who think about the starkly differential distribution of entanglement in terms of porosity across distinct lifeworlds. In investigating what Vanessa Agard-Jones (2016) calls the "chemical kinships" produced on the pesticide-saturated island of Martinique, she describes how some bodies are disproportionately porous, prompting us to think more about the nonlinear effects of toxic chemicals on the poor and the colonized. With a similar focus on the chemical traces of the Atlantic slave trade, Tiffany Lethabo King (2016, 1035-36) writes of eighteenth-century indigo plantations in the American South, where the site of indigo processing was a "rank and putrid smelling zone infested with flies. It was a place on the plantation where it was hard to breathe and a zone many avoided," which meant that "the enslaved toiling there were not always within the master's immediate field of vision." While the chemicals that seeped into the pores of the enslaved contributed to their early deaths (death came five to seven years after starting to work the indigo [BalfourPaul 1998]), King (2016, 1037) argues that this toxicity provided "new geographies of Black freedom.” Putrid toxicity disrupted the master's gaze.

Agard-Jones and King are grappling with the legacy of capitalist expansion, which valorized those who experienced the self as stable, free, sovereign individuals separate from nature who could control or manage what-gets-inside. Their analysis deepens my concern that entanglement constitutes an extremely imperfect means for understanding unequal lifeworlds. My intention, then, is not to discard entanglement altogether, but to point to how those living in the shit (who, in fact, don't need anthropologists, STS scholars, or even Marx to explain how objects are made of relations) often seek boundaries between objects, as well as the stability that boundaried objects have to offer. In other words, entanglement is not always welcome, even in highly relational worlds. It depends on the how and the what and the when. 
Agard-Jones's and King's postcolonial feminist explorations of chemical kinship neither celebrate nor excoriate the entanglement of porosity, but instead document persistence within it. Adopting their approach allows me to examine both the pleasures and the perils of permeability, porosity, and penetration in contemporary Mexico City. With Agard-Jones and King as guides, we can ask: With what are we permeated or penetrated, and to what effect? As countless sexual bottoms of any gender or persuasion can attest, penetration can be pleasurable (Bersani 1987; Brown 1992). Key to the pleasure or lack of it, though, is: by what, and how? Different penetrations produce different effects. They are not all the same.

Permeability is the state or quality of a material or membrane that causes it to allow liquids or gases to pass through. Porous is a synonym for permeable, "having minute spaces or holes through which liquid or air may pass . . . not retentive or secure," as the Oxford English Dictionary (OED) would have it. Penetration also involves a passing through, but it is not synonymous with the other two words; it ratchets up the violence: the OED proposes "succeed in forcing a way into or through," or "insert the penis into the vagina or anus," or "infiltrate (an enemy group or rival organization) in order to spy.” And then there is persistence, which the OED defines as "firm or obstinate continuance in a course of action in spite of difficulty or opposition . . . the continued or prolonged existence of something." As I'll trace out below, I am interested in how persistence might exist despite permeability and porosity — and also because of them.

The historian of science Hannah Landecker's (2013) explication of metabolism allows for further reflection on persistence. Standard models of homeostatic metabolism involved and still involve a model of the body-as-combustion-engine, taking in fuel and putting out energy while remaining distinct from that fuel. In contrast, some philosophical biologists and biological philosophers have proposed metabolism as a third space, where matter is exchanged with its surroundings, producing an "open inwardness" (Landecker 2013, 217). In this framework, metabolism does not burn energy directly but converts it into a milieu intérieur that makes self. Distinction between self and other lies not on the surface of bodies but deep inside, in the energy reserve, or the pool that is not quite the organism or the environment but the moving zone in which the "two become one" (Landecker 2013, 223). What-gets-inside makes the self that can dynamically persist.

Both Señora Nati and Dr. Arias seek stable states within the flux of the environment, for themselves and for others. But where Dr. Arias posits impermeability with her assertion that resilient kids can prevent life conditions from 
penetrating their bodies, Señora Nati manages porosity for persistence. Like most Colonia Periférico residents I know, she is concerned with living well in the reality she inhabits. The aspects of that reality that particularly interest me here are an acceptance of porosity to toxins that act as boundaries against worse penetrations, and the social and bodily density that these boundaries protect.

\section{TOXICITY AND MALA FAMA}

Colonia Periférico has multiple boundaries that allow for persistence. Entering the colonia by vehicle involves passing under a freeway interchange near a Costco, then over a congested boulevard where new luxury condos rise and through an odoriferous zone of recycling and garbage processing, junk-food distribution centers, and dusty factories established near the now-defunct sand mines that made the cement that built midcentury Mexico City. Walking in through this passageway leaves you covered in fine cement residue. The smell hits at the entrance to Colonia Periférico, at a river overpass downhill from Señora Nati's house. Three civic buildings converge at this spot: one of Colonia Periférico's two elementary schools, a corrugated-metal community center with a playground, and a security module manned $24 / 7$ by three rotating policemen with varying attitudes toward Colonia Periférico and its residents. For all practical purposes this marks the only entrance for vehicles, but there are many more by foot.

This entrance alone opens to Colonia Periférico's main artery, Calle Benito Juarez, a street that rises up a hill covering the sand mines below. All day and in the early evenings Benito Juarez is clogged with cars, combis (microbuses), and delivery trucks, often leading to a complete impasse. Instead of heading up Benito Juarez, you could enter one of several narrow callejones (alleys) or drive or walk alongside a long embankment wall, topped by a cyclone fence that serves as another border. More junk-food factories lie on the other side. The embankment is littered with garbage and cans of activo (pipe glue solvent that provides hallucinations when inhaled), and sometimes serves as a stage for graffiti contests and rap groups protesting police violence.

The dam is upriver from the security module. Topped by a causeway, the dam is the strongest stink point in Colonia Periférico. The causeway was landscaped not long ago with astroturf and exercise machines linked to the public health campaign Chécate, Mídete, Muévete! (Get regular check-ups, monitor your weight, stay active!). In the dry season officials send crews and heavy machinery to dredge the dam of the garbage that plugs the grates where the water sluices through. This act is repeated the year after, and the year after that. Colonia 


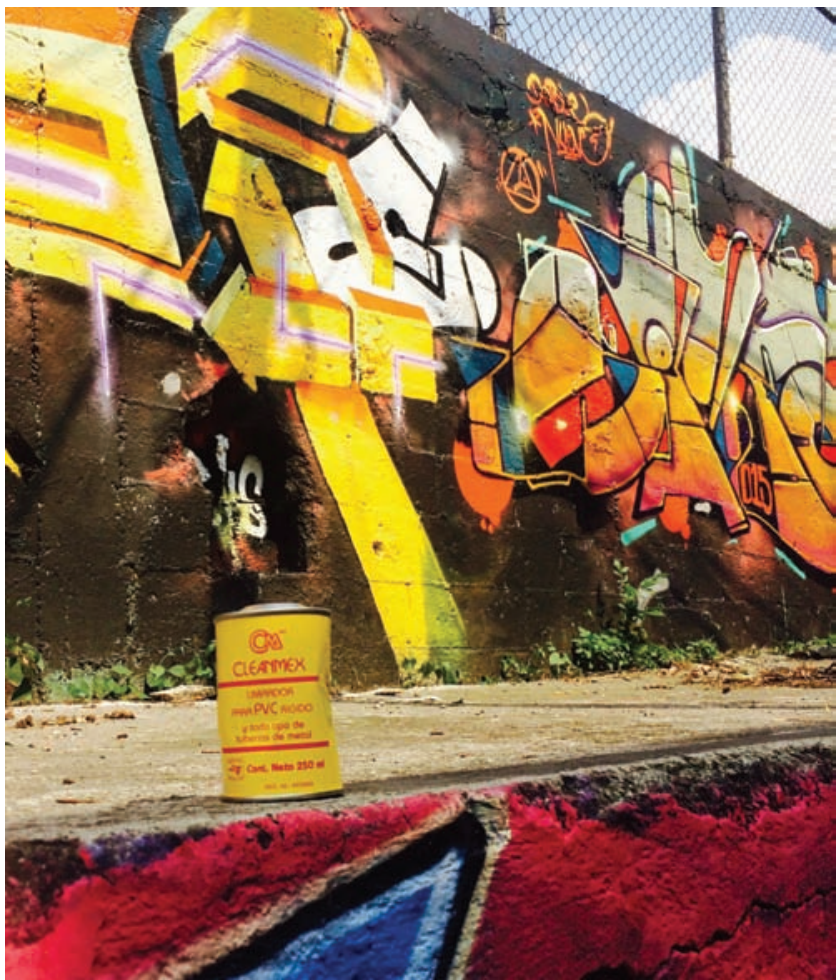

Figure 1. Activo can on the embankment wall. Photo by Elizabeth F. S. Roberts.

Periférico is the last residential stop for a system of dams that control this particular river before the aguas negras head underground. Thus the stench has maximally accumulated as the sewage moves down from on high.

Colonia Periférico's boundaries are also marked by death. Santa Muerte (Saint Death) guards the dam entrance and also the border between Colonia Periférico and El Caracol, a less established colonia near the security-module entrance. Santa Muerte is an unusual saint in that she was never a person whose virtuous life can be emulated. Patron of the marginalized, the incarcerated, the queer, and the poor, La Flaquita, La Niña Blanca is the great equalizer-since everyone dies (Roush 2014). She is linked to the Aztec goddess of death, Mictecacihuatl, and the Catholic Church forbids her worship. Outside of Colonia Periférico, respectable people do not interact with her. Inside Colonia Periférico, even those who want nothing to do with Santa Muerte maintain respect for her and her devotees, explaining simply, "A cada quien sus cosas [to each their own]." 


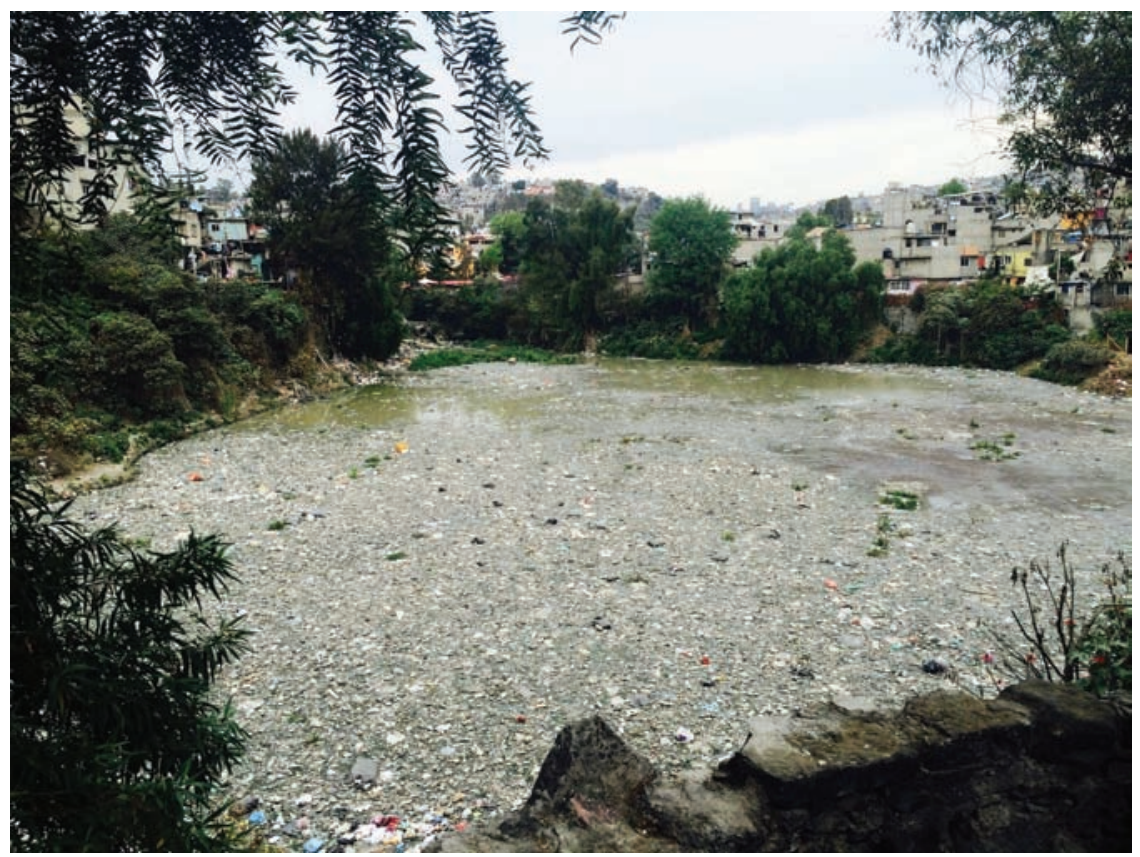

Figure 2. Above the dam. Photo by Elizabeth F. S. Roberts.

These junctures of dam, smell, and death bring up encounters with the police — at least for me. Several times police stopped me at Colonia Periférico's pedestrian borders, telling me I could not enter the neighborhood: too dangerous for a gringa. These were the only times I ever felt menaced in Mexico City. One afternoon four policemen tried to stop me from crossing the dam back into Colonia Periférico. But the moment I stepped off the causeway and was back inside, the police stopped as if held back by an invisible wall. They turned and walked away as a group of young men, smoking weed and drinking pulque safely inside Colonia Periférico's boundaries, hurled insults at their backs. At that moment they and Colonia Periférico were impermeable to the police, and so was I.

This is what Menendez, the most seasoned and calm of the three policemen stationed at the security module, tells me - that he and other policemen will not enter Colonia Periférico. They will not go further than ten meters past their post, because then they would be too vulnerable. If they tried to chase someone, la rata (the delinquent) would disappear in the maze of callejones and through the doors opened by the misguided residents who harbor miscreants. Menendez is sanguine about his inability to enter Colonia Periférico. He appears to know every resident who comes by the module, greeting them warmly and letting them use 


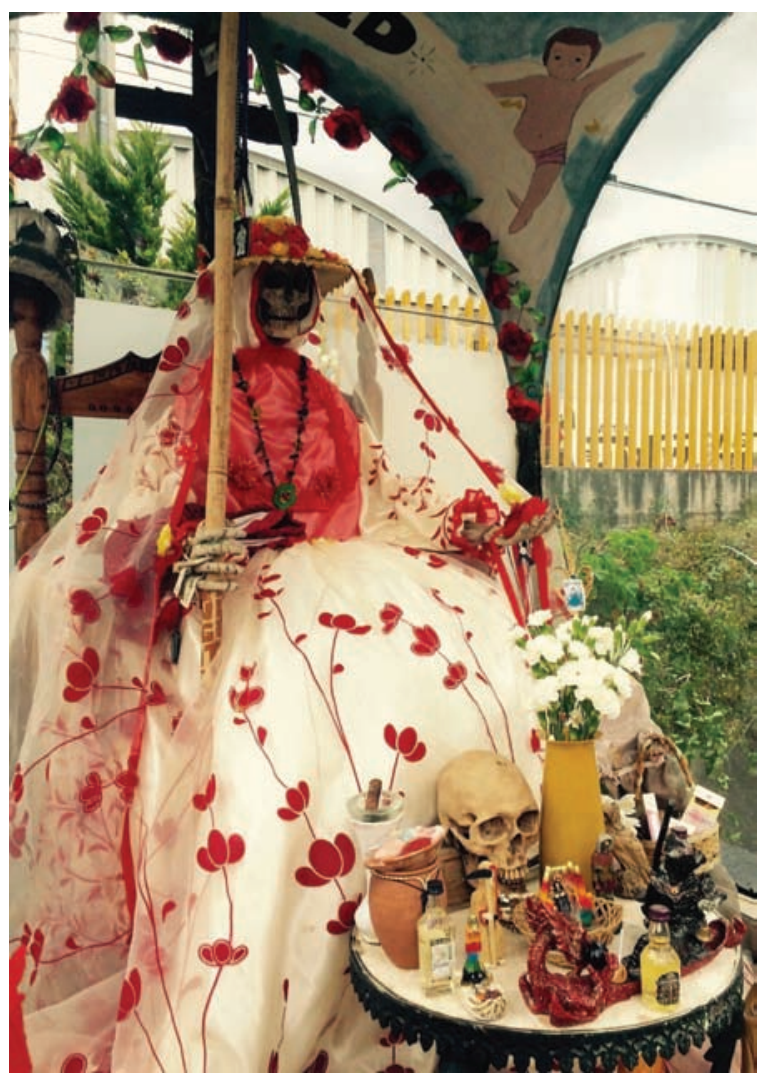

Figure 3. Santa Muerte at the dam. Photo by Elizabeth F. S. Roberts.

the bathroom. The other two policemen, both younger and hotheaded, convey more disdain for the colonia they cannot enter as they explain how Colonia Periférico's boundaries protect dysfunction, violence, and drug use.

The magical invisible barrier does not always hold, however. In the spring of 2015, the police entered Colonia Periférico at the very top of Benito Juarez, shooting and killing a young man who was trying to flee on foot. Nearby, Alma, one of the women whose family I work with, and her two young daughters, Dany and Mar, heard the shots and hid in their bedroom in the back of the house. Two days later police carried out a raid on the home of Colonia Periférico's principal drug-dealing family, the Gomezes, which is safely tucked away in a cul-de-sac three blocks up from Alma's. A few days after that, a house across from Alma's that had been under slow construction for years was suddenly complete. The Gomez family had made it their new base of operations, and now teenage boys 


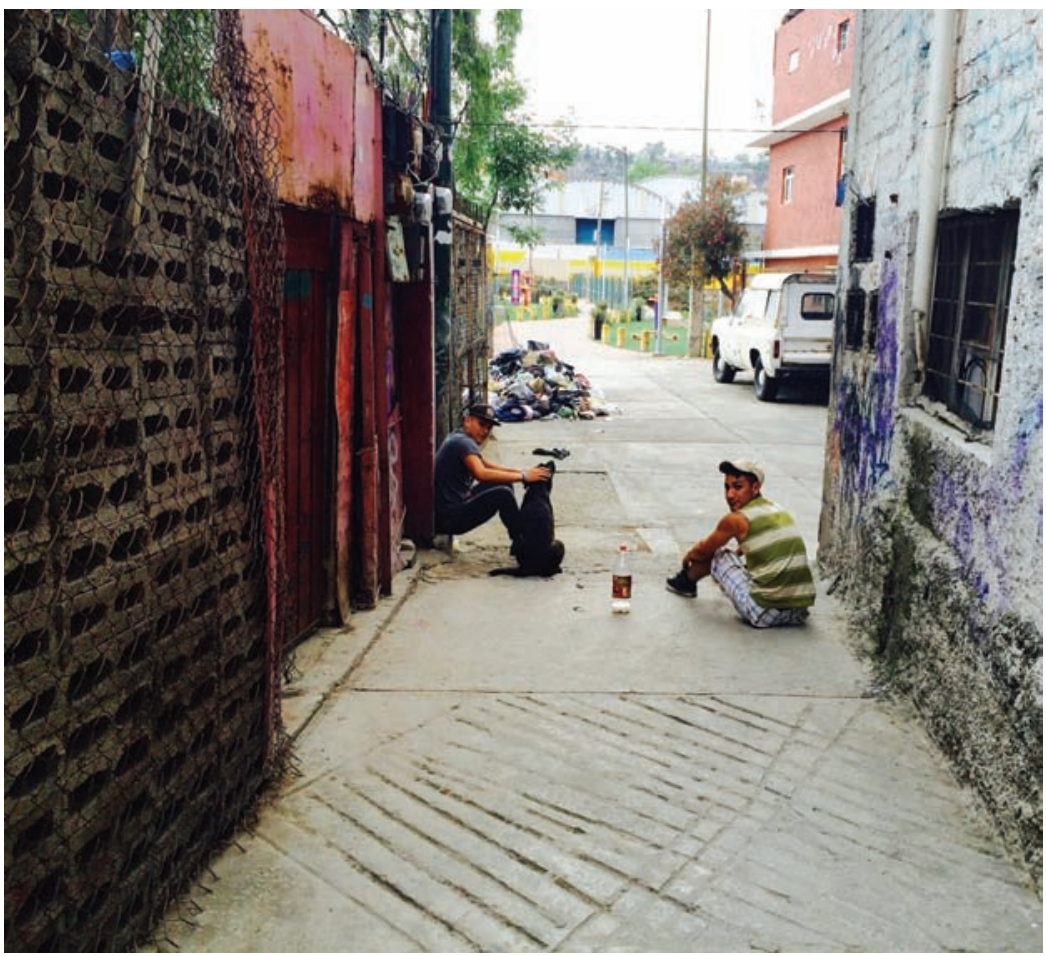

Figure 4. Looking out from Colonia Periférico across the causeway. Photo by Elizabeth F. S. Roberts.

stood in front of Alma's house selling drugs. Alma wasn't angry. She knew the boys and their mothers, who sell her used toys and clothes for her girls. But she did not want Dany and Mar to play on the street while drugs were exchanged in broad daylight. The disruption was temporary. The drug-dealing boys left in midDecember at the start of the novenas for the Virgin of Guadalupe. The police left, too, and haven't been back since.

Colonia Periférico's mala fama extends to other working-class people who live outside its borders, especially taxi drivers, who know it by more than just reputation. Menendez reassured me that I was not the only person whom taxi drivers deposited at the security module after dark, refusing to pass inside, so that I had to walk the rest of the way home. The drivers gave me a litany of reasons for not entering what they knew to be a crime-infested neighborhood. They'd been robbed in Colonia Periférico. People didn't pay their fares. Young men surrounded them, reaching in to steal whatever they could grab. Who could blame taxi drivers for their avoidance? 
Soon after I moved to Colonia Periférico in September 2014, I hired two young men to haul some used furniture to Señora Nati's house in a pickup truck. The two were cousins, newly fled from a village in violence-infested northern Mexico. We spent hours together in the cab of their boss's truck, slowly winding our way through rush-hour traffic. The cousins told me they were nervous to enter Colonia Periférico. Was I sure I wanted to live there? But then, perhaps to be polite, they reassured me that now I could tell anyone where I lived and nothing would happen to me, since my hypothetical Colonia Periférico boyfriend would come after them and beat them up.

The violence worked against real boyfriends, too, if they were from outside. A few months after moving in, Lilia, my nineteen-year-old neighbor across the street, told me about the father of her baby girl, who used to beat her when she lived with his family. When she moved back in with her mother in Colonia Periférico, her boyfriend came and threatened them all. The boys she grew up with on the street, her lifelong neighbors, beat him and told him never to come back. She laughed as she told me about the sight of him leaving in humiliation.

Colonia Periférico's protective fama emerged again when Roberto told me his life story one afternoon above the metal workshop where he worked among other young men, tattooed and mohawked, shaping hot iron and steel amid flying sparks and blasting music. We sat in the middle of one of the narrowest callejones in Colonia Periférico, where you can rest your back on one side and almost put your feet up on the other, your body taking up the width of the lane as dogs slink around you and people step over you on the way to buy Friday afternoon chelas (beers). Roberto told me how he and his girlfriend had had a baby that died soon after birth, compelling him to abandon Santa Muerte for the Virgin of Guadalupe. This was after his time in prison, where even guys from Tepito, probably the most infamous colonia in Mexico City, left him alone. In prison, he explained, being from Colonia Periférico commanded respect.

I narrate all of this by way of contrast to my realization, soon after I was ensconced in Señora Nati's house, that I had never felt so safe in my life. Inside Colonia Periférico everyone knows each other and kids play on the street. You need to say hello to everyone on entering and goodbye when exiting. Walking up Benito Juarez takes forever because of how many people must be greeted. People from Colonia Periférico who now live elsewhere told me that they miss the "knowingness." This entangled knowingness partially comes from the fact that outsiders have no business in Colonia Periférico. There are no chain stores, not even the ubiquitous OXOXs and 7-Elevens that permeate all of Mexico City, 
because of franchise owners' fears of theft. That means all of Colonia Periférico's abarrotes are family-owned.

It would be hard to overstate the density of interaction in Colonia Periférico, especially from late October around the feast day of St. Jude, the patron saint of lost causes and the disenfranchised, through Candelaria on February 2 (which celebrates the presentation of Jesus at the temple). This period unfolds a stream of holy days marked by nightly street parties, which are usually preceded by a mass. Frequent novenas, processions, velorios (wakes), quinceaños, First Communions, and children's birthday parties take place in the middle of the street, with everyone moving to the side when cars need to pass. Neighbors passing by often join in. Different parties spill over into each other (see Duhau and Giglia 2008).

At most of these parties I receive lessons on becoming naco (in my case, naca), especially through vocabulary and tone of voice. While it usually denotes an insult marking one as vulgar, unrestrained, tacky, and low-class, naco, in Colonia Periférico, is a badge of honor. Naco pride and Colonia Periférico pride go hand in hand, an embrace of the located excess wrapped up in naco's Nahuatl root, said to mean "of this place." With wild laughter almost always to the point of cackling, heavy makeup, big hair, and big tattoos, household display niches filled with multiple saints that are often exact replicas of each other and covered in a phantasmagoric array of twinkling lights, packaged baby formula, and garish and plentiful soda bottles, heavy bellies spilling out of leopard-print leggings, loud music, and intensive sociality, Colonia Periférico is lived through an unrestrained, exuberant density of entangled excess.

Colonia Periférico's density makes for close quarters, allowing many forms of chemical kinship. People's livelihoods colonize the cramped streets, mostly without eliciting complaints. Cars and pedestrians have to maneuver around temporary stalls selling fruit, underwear, costumes, saints, and pirated DVDs. Some of these livelihoods are noxious, from car painting that takes over the sidewalks with fumes and spray emanating outward, to wood workshops with clouds of dust pouring out, to the metal shop releasing its acrid plume on the hill above the dam. Such street businesses are noisy, too, though they cannot drown out the cacophony of speakers blasting from roofs or the chained dogs barking.

Nearly everyone tells me that Colonia Periférico is safer than it was before, or when they were young. There are multiple theories as to why. Some say there were neighborhood delinquents, who are now dead or in prison, or else they grew up. That could be true. Time and geography seem part of this story as well. The density of knowingness has had more time to grow since the initial land 
invasion, and so have the boundary-making membranous ramparts: the cement plants, the freeway, the junk-food factories. The defenses have also grown through smell — the garbage and shit. The dam used to be a soccer field half the year, and during the rainy season the river ran so clean you could swim in it. It drew people from the surrounding colonias. Now the dam marks a boundary that permits passage, but who would cross this shit isthmus, except for those who live inside?

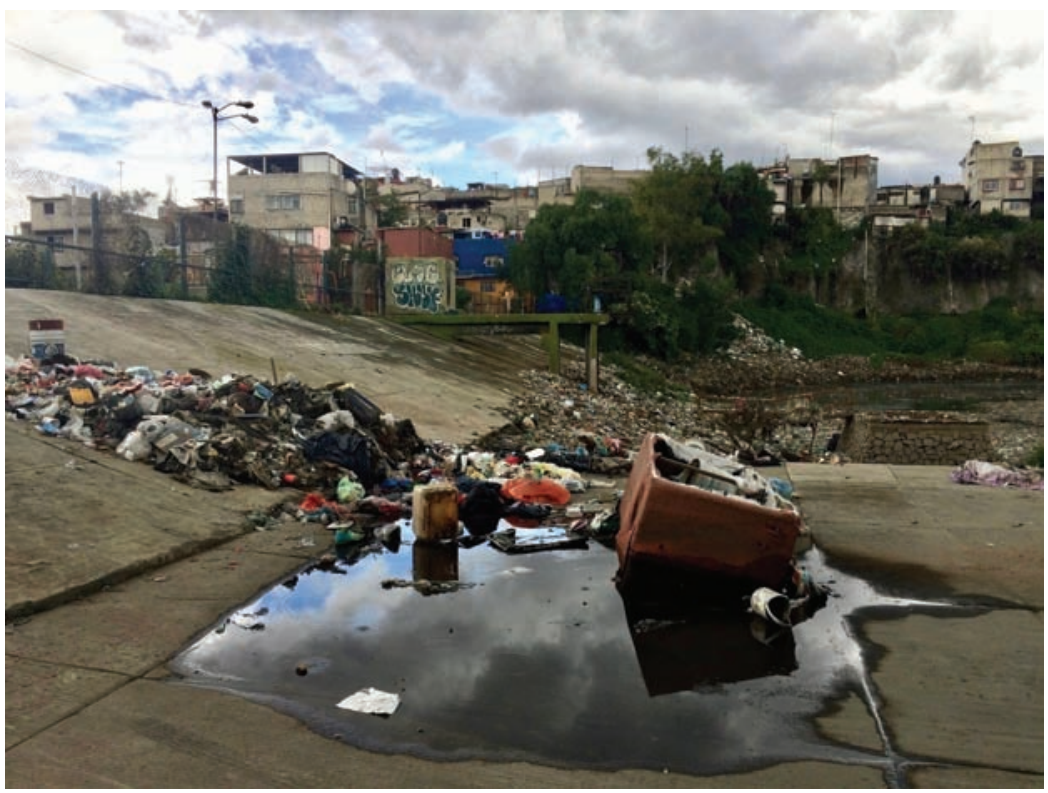

Figure 5. Looking into Colonia Periférico across the causeway. Photo by Elizabeth F. S. Roberts.

The specific era of Colonia Periférico's founding made these ramparts possible. Colonia Periférico is a land-invasion neighborhood. It was settled by paracaidistas, colonists mostly from rural Mexico who squatted land in the early 1960s through the early 1970s (Cornelius 1975). They erected impermanent structures made of cardboard and plastic in winding patterns determined by the ravines and sand mines. I cannot imagine hearing about this settlement process from those who lived it without being moved by their labor and achievement in making it happen. They obtained services like water, sewage, electricity, and transportation, and they built the roads and schools themselves with materials from Partido Revolucionario Institucional (PRI) officials. Luckily for the residents of Colonia Periférico, they were petitioning for these resources in a midcentury moment of great international focus on poverty and slum reduction through land titling. For 
the colonists this international focus combined fortuitously with Mexico's oneparty, paternalistic PRI rule, which secured votes from colonists by providing services and land titles in colonias throughout Mexico City (Lomnitz-Adler 1993).

The dynamics of Colonia Periférico's current era make these ramparts more necessary. A growing literature now demonstrates that the North American Free Trade Agreement (NAFTA), signed into effect in 1994, and the War on Drugs, declared in 2006, are of a piece in terms of their effects on Mexico (Paley 2014). Together, they have caused rural land dispossession on a massive scale that makes these lands and resources like water available for transnational corporations to exploit; increased both internal and external migration; intensified militarization, including that of the police; furthered the privatization of public services and land; restructured the legal system; and increased Mexican body mass, all to the benefit of transnational corporations.

Many accounts of the effects of NAFTA and the drug war leave out Mexico City, except as the overflowing receptacle for dispossessed people fleeing the violence. Mexico City is currently experienced as a much safer place than it was in the 1990s and early 2000s, when kidnappings and public murders abounded. A story circulates that the cartels have designated Mexico City a safe zone, a negotiation space where their families can live. Recent Mexico City nightclub massacres and assassinations of journalists fleeing from violence complicate that story. Indeed, NAFTA and the drug war have transformed life in Mexico City at every level. Large-scale land dispossession cannot occur in such a dense urban area, but the Carlos Slim-style gentrification of the historic center (Leal Martínez 2007, 2016; Pérez Negrete 2016) — the ubiquity of big-box chains like Home Depot and Walmart, which cut jobs while claiming to create them-adds to increasing instability for working-class people. Moreover, with national crises like the 2014 mass kidnapping of students from the Ayotzinapa Rural Teachers' College and the continual discovery of mass graves across the nation, NAFTA and the drug war have, even in the supposedly cartel-free, violence-free zone of Mexico City, caused everyday life to hang by a thread.

But Colonia Periférico seems to be holding steady against these transformations, helped by earlier land-title programs. Señora Nati's house title is in her name. She paid for its construction with savings she earned by selling her embroidery. Her now-deceased husband's wages as a taxi driver supported daily life during the construction. Built continuously from the 1970s through the 1990s, Nati's house is now a compound with six separate units that have throughout the years housed her husband, her four children, and several grandchildren and great- 
grandchildren, as well as boarders. Señora Nati has done well with her house. She paid 1,500 pesos for the title in the 1970s, which was cheap even then. She now estimates that her house is worth a million pesos. She is proud of how well built it is, and how well she maintains its security, from sweeping the street in front every day to strictly controlling who has keys.

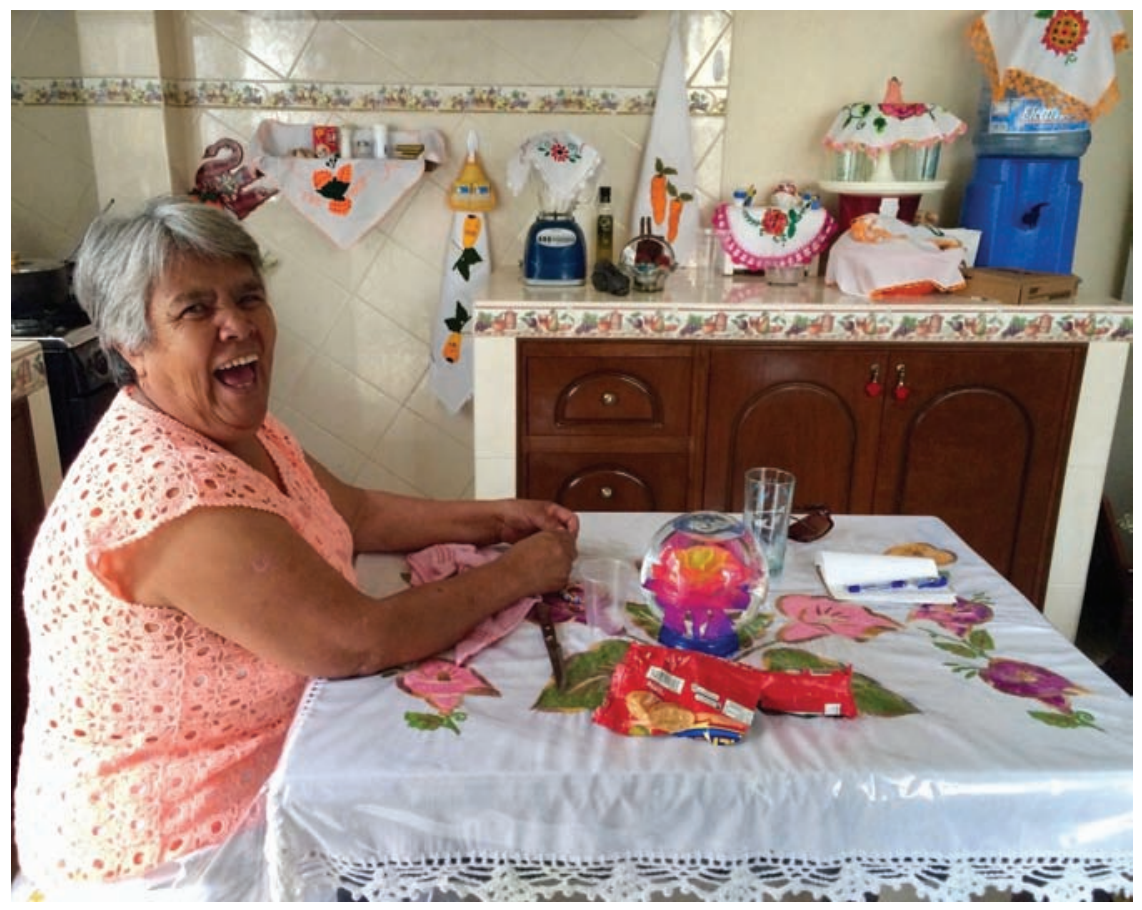

Figure 6. Señora Nati in her sparkling clean kitchen with her bordados (embroidery). Photo by Elizabeth F. S. Roberts.

Señora Nati's household resembles the majority of those I got to know in Colonia Periférico, where homes housed up to four generations and families held the title, often in an older woman's name. No one who lived with their natal family paid rent. These conditions brought an extraordinary level of stability to Colonia Periférico residents, ${ }^{2}$ who did not have to contend with the evictions so common to working-class, poor, and, increasingly, middle-class people in nations, regions, and cities with skyrocketing real-estate markets (Sassen 2014; Desmond 2016). Real-estate prices and speculation and new luxury high-rises are rife in Mexico City, including areas just outside Colonia Periférico. The nearby colonia of Santa Fe, with its high-rise ultra-luxury apartments and chic shopping malls, 
displaced thousands of low-income households, though the official narrative claims that it was built on an uninhabited dump (Moreno Carranco 2010; Shoshan 2015). Colonia Periférico residents tell of shopping-mall developers coming around a few years ago, but losing interest because of the stench and reputation.

After living in Colonia Periférico for six months, I lived another half-year in Buena Vista, another working-class neighborhood, working with three families who were also participating in the environmental health study. Situated in the foothills of the mountains that ring Mexico City to the south, Buena Vista feels bucolic and almost village-like. My small house sat within a family's larger compound, which also housed horses, sheep, chickens, and dogs. Buena Vista was not a land-invasion neighborhood. Lots were laid out in a precise grid and sold to buyers in the 1970s and 1980s, which means that its wide streets have right angles, unlike the windy and confusing callejones of Colonia Periférico.

As in Colonia Periférico, the three families I worked with had title to their land and homes, but household compounds all around them were in the process of being bulldozed to make room for new condos. The beginnings and ends of Buena Vista are not obvious, running into other unboundaried colonias that all feel the same. Unlike Colonia Periférico, Buena Vista is located on major transportation routes and participates in inter-colonia commerce. Unlike in Colonia Periférico, taxi drivers drove me all the way home at night. Walking in Buena Vista, with its right angles, fresh air, and wide vistas of forested mountains, does not feel like walking through intestines. But the sense of peace was illusory. Storeowners commonly experienced police shakedowns. There were signs hung on houses every few blocks warning ratas of zero tolerance for crime. I did not like to walk alone at night. At night the streets are empty. The neighborhood's flow, size, and openness make it harder to know or be known in Buena Vista. Despite its good reputation, Buena Vista does not feel safe for its residents. Its lax permeability allows for instability.

As a point of contrast, Buena Vista made clear what Colonia Periférico's toxicity and mala fama provide. Colonia Periférico was the opposite of every U.S. middle-class coastal or college-town neighborhood I have known, where even before the hyperfocus on organic food and Bisphenol A-free baby bottles, there were assumptions about the ability and right to protect one's insides (Biss 2014). For the U.S. middle class, protection occurs without any visible boundaries - the benefit of a century of zoning laws favoring the middle class. In a curious way, Colonia Periférico more closely resembles the gated communities that academics in the United States so disdain. Like the wealthy who live inside these walled 
zones, residents of Colonia Periférico are able to protect the insides from the outside, even as NAFTA and the War on Drugs rage on. Stability in Colonia Periférico is predicated not on gates and private security guards, but on the mala fama and toxicity that permeate the bodies of its residents and that enable their persistence.

\section{PROTECTIVE POROSITY}

Besides the police, Colonia Periférico is stubbornly impenetrable to the territorial incursions and educational interventions of public health surveillance, especially those interventions that target people as individuals with regard to their and their children's health. While keeping public health surveillance out, Colonia Periférico lets corporate processed foods inside the bodies of its residents, much like spray paint and the stink of the dam. Processed chemical substances like soda increase persistence through social pleasure amid daily injuries exacerbated through the effects of NAFTA and the drug war.

One of the clear successes of NAFTA and the War on Drugs, which together provide a more favorable environment for transnational trade in Mexico, was making processed and sugary foods and beverages cheaper and more available. Subsequently, Mexico's designation as the world's fattest industrial nation by the WHO in 2013 threw Mexico's individualizing public health anti-obesity efforts into overdrive, with a special focus on soda, identified as one of the key drivers of the so-called obesity epidemic. Billboards, TV advertisements, and new regulations inform the populace of soda's harm. Approaches like these do not necessarily get working-class people to drink less soda. But they do work to amplify class divisions. One of the most palpable differences between upscale and working-class or poor neighborhoods in Mexico City (as in much of the urban world) is body size. Upscale neighborhoods are thin, while everywhere else is fat. Colonia Periférico is no exception.

The proposed alternative to soda is water, but water is simply not reliable. In many neighborhoods, tap water only comes a few days a week, and even then it is not seen as safe to drink. Working to make water more available, more reliable, and less expensive than soda might be impossible as long as Mexico is Coca-Cola's number-one market and the largest consumer of bottled water in the world. Legally, all water in Mexico is national patrimony, making water of the state, which no one trusts. Unlike many working-class neighborhoods Colonia Periférico tends to have running water almost all the time, while trucks selling bottled water do not always get in. Other deliveries do get through, though: 
Coca-Cola, Sabritas (chips and other snacks), and Bimbo (white bread and snack cakes) trucks clog Benito Juarez all day long, backing up traffic to the main entrance.

This power to get inside is unknown to the police force guarding Colonia Periférico's entrance. It is also a power unknown to social and health workers. The director of the local seguro popular clinic, which serves Colonia Periférico and other nearby low-income colonias, was stunned when she heard that I lived inside. She explained that she could not complete health surveys in Colonia Periférico because her workers were too afraid to cross its borders. In the landscape of social services administered by the delegación (borough), Colonia Periférico is a punto rojo (problem area). In meetings, interviews, and informal conversations, social workers, those charged with making Colonia Periférico less marginalized, described the neighborhood to me as an abject and dangerous cesspool of violence, drugs, and broken families. It came to seem as if the colonia was designated a punto rojo precisely because of its successful resistance to pastoral ministrations, a virtue difficult for these state actors to imagine.

One thing that the social workers and police get right is that drugs are done inside Colonia Periférico, and those who do them, mostly young men, do them in public. What would be difficult for them to know is that in many ways, public drug-taking contributes to Colonia Periférico's persistence. Two drugs dominate the streetscapes - marijuana and activo. Marijuana is a social drug. On Señora Nati's street, the same group of young men smoked joints together every evening, leaning against hollowed-out cars yet to be repurposed. The young men smoking weed, and sometimes drinking beer or pulque, were unfailingly polite. They chatted with passersby at all hours of the day or night. They are the same group that beat up Lilia's abusive boyfriend and hurled insults at the police at the edge of the dam causeway. Older men smoke weed, too, on the steps winding up Benito Juarez with their friends. You step around them as you greet each other.

Activo, a pipe glue solvent easily purchased at hardware stores, provides hallucinations on the cheap, but is much less social. The young men who inhale it usually do so alone, or sometimes together, yet alone, on religious pilgrimages. They stare into space, sometimes shadowboxing the air while muttering. Yellow and red activo cans litter the callejones and the graffiti wall bounding Colonia Periférico. Activo users are usually very thin. As my eyes became accustomed to the heavy naco bodies of Colonia Periférico, I began to wonder about any thin man. Does he use? Or has he no women to feed him? 
Like most of the grandmothers and great-grandmothers I know in Colonia Periférico, Señora Nati is both moralistic and philosophical about drug use. She attributes drug use to the failure of families, not economic decline. But she does not blame the user. Her godson across the street uses activo. She speaks fondly of this rail-thin young man with a permanently glassy stare. She tells me how, when he is not inhaling, he is sweet to her and she feeds him. Another activo user, Osvaldo, is always stationed on the street near the bakery. People give him food and sometimes odd jobs. He is treated much like Eva and Rodrigo, cognitively disabled siblings who are constantly put to work throughout the colonia hauling garbage and sweeping. Accepting public drug use marks a striking nonacceptance of the terms of the War on Drugs, which in the name of health forces drugs underground. The very public nature of their drug-taking within Colonia Periférico's boundaries allowed activo users safety, enmeshed in the care of a colonia that integrates drug users and disabled residents into everyday life.

Even with public drug use, residents' bodies are much more permeable to soda than illegal drugs. The post-NAFTA and War on Drugs dissemination of soda is wider and more profitable. With soda, as with illegal drugs, public health efforts exist to prevent penetration. But it proves difficult to undercut consumption when soda is so cheap, reliable, and social as compared to water. In Colonia Periférico, soda lubricates social life at every meal and nearly every moment in between. Super-sized sodas are a constant at gatherings. With prompting, most residents link it to ill health, maybe fatness, maybe diabetes - but all of these "maybe," in the future. They all point out that it costs almost no more than water, even after the soda tax. It tastes better. It's rude not to offer it to others. Who would share water? Some men tell me, laughing, that they once tried to stop because they heard it might cause problems later, but they only lasted a few days. Laughing harder, they declare "it's more addictive than what the narcos sell," their knowing laughter resonating with Angela Garcia's (2010, 2017) devastating portraits of both northern New Mexico and Mexico City, where there is no outside to either addiction or the War on Drugs.

Besides the anti-soda TV ads and the billboards blanketing Mexico City, parents know that soda is the enemy because of recent guidelines that prohibit children from taking it to school. Only water, agua natural, is allowed. In 2014, about seven months before the shooting of the young man by the police at the end of their street, Alma and Mar showed me how they break this rule, both giggling mightily. Mar would not drink agua natural. She wanted the corporeal joy that flavor and sugar provide. Lovingly, Alma wanted Mar to have more. She 
bought clear soda and poured it into clear plastic water bottles to fool Mar's teachers. A year later I asked Alma if she was still sending clandestine soda in Mar's lunch. She laughed even harder than before and told me that the teacher caught her, and other mothers doing the same, and said, "Mamita, if they're thirsty they'll drink." The teacher now smells and tastes the liquid that comes to school with kids.

Providing soda is one act of loving care in Alma's broad repertoire. She is an avid biopoltical subject, as she seeks state services outside of Colonia Periférico, diligently signing her kids up for city enrichment programs and carefully keeping track of all their doctor's visits through Mexico's comprehensive IMSS healthcare system. She has their medical passbooks always at the ready, neatly filled out, documenting their every ailment. Dany's and Mar's near-constant supply of antibiotics and asthma medications are precisely arranged on the table in the middle of the living room. She knows the long generic names of all the medications the girls take. Alma cooks only with bottled water. Alma, who is diligent about the health and safety of her kids, does not restrain her kids' caloric intake but gives them more whenever she can. Her household of nine is heavy except for Mar, who is only six. Soda allows Alma to stabilize Dany and Mar as they learn how to inhabit the unstable environment outside of Colonia Periférico, which seems invested in their existence only insofar as they can be chastised for their naco fatness or as excessive naco consumers of soda. Of the two options, soda provides so much more.

Being more permeable to soda and less permeable to anti-obesity messages makes sense in Colonia Periférico, but this does not register with public health efforts that call for resistance to soda (see Yates-Doerr 2012). These efforts resonate with public health campaigns worldwide that call on people, as individuals, to remove themselves from forms of sociality necessary to their very survival. For instance, ongoing U.S.-based public health campaigns that tell IV drug users not to share needles do little if you are a homeless IV drug user, and the people with whom you share needles are the same people who have your back (Bourgois and Schonberg 2009). Contemporary U.S.-based safe sex campaigns against unprotected anal sex demonize both black men who have what they call "raw" sex with other men and white "barebackers" for engaging in welcome and pleasurable communitas after decades of exhaustion from living in an epidemic amid ubiquitous racism and homophobia (Bailey 2016; Dean 2009). And Brazilian campaigns advocating breastfeeding in the 1980s did not acknowledge how, in shantytowns, feeding infants formula instead of breast milk was a crucial means of distributing 
responsibility to male partners, who paid for a child's sustenance (Scheper-Hughes 1992). In such instances, whether chemical kinships flow through heroin, semen, infant formula, or soda, survival depends on permeation - of socially shared substances and substantive sociality. Public health poses these substances as threats to individuals' lives, but it is crucial to recognize how they provide what I understand as protective porosity, which sustains life at collective levels. Like the shit, cement dust, graffiti, and twisting callejones that contribute to Colonia Periférico's protective porosity at the territorial scale, soda distributed at the bodily scale between family members and neighbors can serve simultaneously as both hazard and protection.

Colonia Periférico's ability to persist territorially through the protective porosity that shields it from the penetrations of NAFTA, the War on Drugs, and Mexico's public health apparatus prompts an examination of Dr. Arias's invocation of resilience. Why is Colonia Periférico characterized as the kind of place to which children must become resilient, rather than celebrated as a neighborhood that is resilient because it can resist penetration? Like the homeostatic model of metabolism, resilience assumes a self that persists, staying the same by "avoiding the negative effects of risk to exposure . . . [and] the negative trajectories associated with risks" (Fergus and Zimmerman 2005, 399). Of course, only certain kinds of persistence are rewarded as resilient. We are "less willing to judge an individual as resilient if, against the odds, she becomes a wealthy and successful criminal” (Allmark, Bhanbhro, and Chrisp 2014, 3).

Similarly, Colonia Periférico is judged perversely impermeable to the ministrations of state management and as entangled in substances that are designated as harmful - drugs, bacteria, soda - but that provide persistence through social stability. In the American South, toxicity both protected and poisoned enslaved workers on indigo plantations; in Mexico City, toxicity prevents surveillance and violence for Colonia Periférico and its residents, even as it may make people sick. Within the standard public health and social work frames of resilience, it is difficult for state actors to imagine these toxic entanglements as protective. The problem with resilience is that it partakes in individualizing logics by leaving larger structures unaddressed. I worry, though, about entanglement as an alternative, because it may not provide much more solace than resilience to those who live amid the toxins. 


\section{ENTANGLEMENT'S DISCONTENTS}

By August 2016 Alma was trying to drink less soda. This might seem like a public health victory, but the lesson is not so clear. At a routine clinic visit in July, Alma and her husband Juan had both been diagnosed as prediabetic. Laughing, Alma and Juan narrated the inexplicability of this diagnosis. Juan is heavy, but has rarely drunk soda or eaten sweets. Unlike Alma, he does not spend his life inside Colonia Periférico. He works six days a week outside the colonia installing commercial security systems, a salaried, fairly stable job. And yet Juan is just as prediabetic as Alma, who has a sweet tooth with a vengeance. "You know me," she says, "always with my candy"; she mimes dipping into a bag of sweets. The lack of sense in Juan's diagnosis prompts questions. Why quit soda when prediabetes can arrive without it? How do you change your diet to prevent diabetes if you do not eat sweets? These uncertainties underscore something increasingly clear in nutrition, exposure science, and toxicology: substances do not have reliable, explicable, or linear effects.

To isolate variables that document linear effects, knowledge claims, and public policy recommendations about chemicals and nutrition in the life sciences and in public health are based on large samples that become numbers. As anthropologists and STS scholars committed to entanglement and uncertainty, we know linear thinking constitutes a problem. Linear thinking shuts down the possibility of tracing how chemicals might be engaged in looping relations with bodies situated in their specific worlds (Lock and Nguyen 2010). As Michelle Murphy (2004, 267) argues, focusing on a single signal, a single variable, a single chemical entails a "learned inattention to other noise." Linearity is modernity itself, delinking the chains that bind to make new autonomous objects. It is important, then, to foreground a critique of the isolationist, linear tendencies baked into environmental and public health. These tendencies tend to universalize bodies while individualizing behavior - for instance, in anti-obesity campaigns that fail to account for a radically transformed food landscape and the multiple destabilizations of NAFTA and the War on Drugs, and in chemical-exposure studies that decontextualize lead from poverty (Lock and Pálsson 2016).

In science and technology studies, entanglement is a means for knowing the world better. Entanglement and nonlinear thinking allow us to ask: If people breathe shit, might they be more or less affected by soda? Can the stress people experience from police violence be mitigated through protective social density? How might the vast transformation in the post-NAFTA and War on Drugs food landscape, along with increased body mass, affect Bisphenol A uptake? How might 
these changes change the actual composition of the chemicals, bodies, or economic policies? Entanglement could allow us to ask: why is Juan prediabetic when he does not drink soda?

As we shift our efforts to loop and entangle phenomena amid the uncertainty, however, we need to notice the effects of leaving linearity behind. Boundaries and linear models might constitute a necessary response in places where life must always be lived as improvised and ceaselessly entangled, and where objects (like water) are never stabilized apart from their relations (Roberts 2017). For many of the world's inhabitants, the entanglement of everything with everything proves relentlessly exhausting. Indeed, I am pretty sure that the residents of Colonia Periférico would like to share in the privilege of inhabiting a world of objects that can be experienced as bounded from the relations that make them, a world, for example, with reliable drinking water, formal-sector work, and a civil police force. With the goal of knowing the world better, then, science and technology studies might complicate celebratory calls for the uncertainty of entanglement, or for staying with the trouble, by taking into account not only the (often quantitative) practices that make boundaries but also what those boundaries have to offer. In this way, we can avoid celebrations of breathing shit without dismissing the densely social lifeworlds that persist in its inhalation.

Both Dr. Arias and Señora Nati seek boundaries instead of constant entanglement. Dr. Arias is not betting on life conditions getting better in Mexico, so she wants to understand how to prevent the penetration of individual kids as a matter of survival. Within the world she inhabits, Colonia Periférico is the kind of environment to which children must become resilient - impermeable to chaos, drugs, and soda. For Señora Nati, however, persistence entails land, her neighborhood, where bodily permeability to toxicity prevents territorial penetration. Soda gets inside. Spray paint gets inside. Bacteria get inside - a fecal transplant that (in a fun-house mirror image of the Cold War immune system) prevents the penetration of foreign invaders (Martin 1994). Porosity to drugs, soda, and shit stabilizes the borders of Colonia Periférico against Mexico in this time of NAFTA and the War on Drugs. The stink is the price paid: the stink of a life lived in a dense, gut-shaped labyrinth that you miss while staying at your son's empty house in the green and lonely grid of Portland.

\section{ABSTRACT}

Entanglement is a key concept in contemporary anthropology and science and technology studies. By tracing the contingent and uncertain relations that endow objects 
with seemingly stable boundaries, entanglement allows us to see how such boundaries restrict our ability to know the world better. This article examines the concept of entanglement in the context of contemporary life in a working-class Mexico City neighborhood, Colonia Periférico, and a longitudinal environmental health project that studies the neighborhood's residents. While entanglement has its uses, the entanglement of working-class bodies with globalizing processes like NAFTA and the ongoing War on Drugs shows that the concept has its limits. For working-class residents, life is already deeply entangled with chronic economic and political instability shaped through the violent ravages of transnational capital. Instead, I trace how residents in Colonia Periférico secure stability through toxic boundaries that protectively keep out the disruptive effects of police and public health surveillance. Colonia Periférico's boundaries, which include a sewage-filled dam, cement dust, and freeway exhaust, are clearly entangled with residents' bodies. They get inside. These entanglements are the price paid for a remarkable stability, in which children can play on the streets and attentive care for drug-addicted and disabled residents is part of everyday life. With the goal of knowing the world better, then, we might complicate celebratory calls for the uncertainty of entanglement by taking into account both the practices that make boundaries and what boundaries have to offer. [entanglement; toxicity; contamination; environment; resilience; Mexico City; public health; urban anthropology; neighborhood studies]

\section{NOTES}

Acknowledgments Dean Hubbs's insistently careful engagement with my still murky ideas and prose finally made it clear to me that this article was about entanglement and its discontents in Colonia Periférico. Developing that argument came about through a wonderful series of collective conversations with the insightful readers in the Oxidate working group and the Anthropology and History workshop at the University of Michigan; listeners in the Science and Human Culture Program at Northwestern University, the Center for Science, Technology, and Society at Drexel University, the Center for Social Medicine at the University of California, Berkeley, and the Departments of Anthropology at the University of California, Los Angeles and the University of California, Irvine; as well as my energizing students in the Mexican Exposures Ethnographic Lab. Wayne Cornelius's generous correspondence about Colonia Periférico's early days allowed me to understand change over time. Camilo Sanz, Alaina Lemon, Mike McGovern, Harris Solomon, and Kate Zaloom helped me think more carefully about what I had to say about entanglement, toxicity, and urban life. Two anonymous reviewers from Cultural Anthropology, as well as the editors, have helped me hone my argument further. The National Science Foundation and the Wenner Gren Foundation provided muchneeded resources for spending extended periods of time in Mexico City. Señora Nati, and most everyone else I know in Colonia Periférico, consistently draw my attention to the surprising, sometimes uncomfortable, and always lively ways she, and they, inhabit the world. Thank you all for the many shared pleasures.

1. Colonia Periférico and Buena Vista are both pseudonyms. Recently theorists of ethnographic practice have persuasively argued that anthropologists should not change the names of the places where they work so that they represent place ethically (ScheperHughes 2001). While I acknowledge the importance of this critique, identifying Colonia Periférico by its real name feels untenable, given that its residents and geography endeavor to prevent the incursion of outsiders. The U.S.-based political scientist Wayne 
Cornelius worked in the same colonia in the 1970s and gave it the pseudonym Periférico. My use of the same name maintains continuity for the research archive. I changed Buena Vista's name as well in the interest of parity with Colonia Periférico. I have also changed the names of everyone described in the article, except Señora Nati, who did not want to be anonymized.

2. Stability can be stifling, of course. My neighbor Omar, who suffered little direct homophobia for being uno de los gays in Colonia Periférico, felt the heaviness of this stability. To have the privacy he craved he would have to go elsewhere and pay rent, impossible with his meager earnings as a hair stylist. One trajectory that many young people take toward some privacy in extended households is to have a child, which usually grants them some separate conjugal space. For Omar, this was not an option.

\section{REFERENCES}

Agard-Jones, Vanessa

2016 “Episode 35." Cultures of Energy podcast, September 29. http:// culturesofenergy.com/ep-35-vanessa-agard-jones.

Allmark, Peter, Sadiq Bhanbhro, and Tom Chrisp

2014 "An Argument Against the Focus on Community Resilience in Public Health." BMC Public Health 14, no. 62. https://doi.org/10.1186/1471-2458-14-62.

Bailey, Marlon M.

2016 “Black Gay (Raw) Sex.” In No Tea, No Shade: New Writings in Black Queer Studies,

Balfour-Paul, Jenny edited by E. Patrick Johnson, 239-61. Durham, N.C.: Duke University Press.

Barad, Karen

1998 Indigo. London: British Museum Press.

2007 Meeting the Universe Halfway: Quantum Physics and the Entanglement of Matter and Meaning. Durham, N.C.: Duke University Press.

Bersani, Leo

1987 “Is the Rectum a Grave?” October 43: 197-222. http://www.jstor.org/stable/ 3397574.

Biss, Eula

2014 On Immunity: An Inoculation. Minneapolis, Minn.: Graywolf Press.

Bourgois, Philippe, and Jeffrey Schonberg

2009 Righteous Dopefiend. Berkeley: University of California Press.

Brown, Jan

1992 “Sex, Lies, and Penetration: A Butch Finally 'Fesses Up.” In The Persistent Desire: A Femme-Butch Reader, edited by Joan Nestle, 410-16. Boston, Mass.: Alyson Publications.

Cornelius, Wayne A.

1975 Politics and the Migrant Poor in Mexico City. Stanford, Calif.: Stanford University Press.

Daston, Lorraine

1992 “Objectivity and the Escape from Perspective." Social Studies of Science 22, no. 4: 597-618. https://doi.org/10.1177/030631292022004002.

Dean, Tim

2009 Unlimited Intimacy: Reflections on the Subculture of Barebacking. Chicago: University of Chicago Press.

\section{Desmond, Matthew}

2016 Evicted: Poverty and Profit in the American City. New York: Crown Publishers.

Duhau, Emilio, and Ángela Giglia

2008 Las reglas del desorden: habitar la metrópoli. Mexico City: Siglo XXI.

Fergus, Stevenson, and Marc A. Zimmerman

2005 “Adolescent Resilience: A Framework for Understanding Healthy Development in the Face of Risk." Annual Review of Public Health 26: 399-419. https://doi.org/ 10.1146/annurev.publhealth.26.021304.144357. 
Garcia, Angela

2010 The Pastoral Clinic: Addiction and Dispossession along the Rio Grande. Berkeley: University of California Press.

2017 "The Rainy Season: Toward a Cinematic Ethnography of Crisis and Endurance in Mexico City." Social Text 35, no. 1: 101-121. https://doi.org/10.1215/ 01642472-3728020.

Haraway, Donna J.

2016 Staying with the Trouble: Making Kin in the Chthulucene. Durham, N.C.: Duke University Press.

Keller, Evelyn Fox

2000 The Century of the Gene. Cambridge, Mass.: Harvard University Press.

King, Tiffany Lethabo

2016 "The Labor of (Re)reading Plantation Landscapes Fungible(ly)." Antipode 48, no.

Landecker, Hannah 4: 1022-39. https://doi.org/10.1111/anti.12227.

2013 "The Metabolism of Philosophy, in Three Parts." In Dialectic and Paradox: Configurations of the Third in Modernity, edited by Ian Cooper and Bernhard F. Malkmus, 193-224. Bern, Switzerland: Peter Lang.

Leal Martínez, Alejandra

2007 "Peligro, proximidad y diferencia: Negociar fronteras en el Centro Histórico de la Ciudad de México." Alteridades 17, no. 34: 27-38. http://alteridades. izt.uam.mx/index.php/Alte/article/view/222.

2016 "'You Cannot be Here': The Urban Poor and the Specter of the Indian in Neoliberal Mexico City." Journal of Latin American and Caribbean Anthropology 21, no. 3: 539-59. https://doi.org/10.1111/jlca.12196.

Lock, Margaret, and Vinh-Kim Nguyen

2010 An Anthropology of Biomedicine. Malden, Mass.: Wiley-Blackwell.

Lock, Margaret, and Gísli Pálsson

2016 Can Science Solve the Nature/Nurture Debate? Malden, Mass.: Polity.

Lomnitz-Adler, Claudio

1993 Exits from the Labyrinth: Culture and Ideology in the Mexican National Space. Berkeley: University of California Press.

Martin, Emily

1994 Flexible Bodies: Tracking Immunity in American Culture from the Days of Polio to the Age of AIDS. Boston: Beacon Press.

Mol, Annemarie

2002 The Body Multiple: Ontology in Medical Practice. Durham, N.C.: Duke University Press.

Moreno Carranco, Maria del Carmen

2010 The Socio/spatial Production of the Global: Mexico City Reinvented through the Santa Fe Urban Megaproject. Saarbrücken, Germany: VDM Verlag.

Murphy, Michelle

2004 "Uncertain Exposures and the Privilege of Imperception." Osiris 19: 266-82.

Paley, Dawn https://doi.org/10.1086/649406.

2014 Drug War Capitalism. Oakland, Calif.: AK Press.

Pérez Negrete, Margarita

2016 "Ciudad de México: el camino recorrido en la conformación de una ciudad global.” Revista mexicana de ciencias políticas y sociales 61, no. 226: 331-51. http://

Roberts, Elizabeth F. S. www.revistas.unam.mx/index.php/rmcpys/article/view/53665.

2015a "Bio-Ethnography: A Collaborative Methodological Experiment in Mexico City." Somatosphere, February 26. http://somatosphere.net/2015/02/bioethnography.html. 
2015b "Food is Love: And So, What Then?" BioSocieties 10, no. 2: 247-52. https:// doi.org/10.1057/biosoc. 2015.18.

2017 "Exposure." In "Lexicon for an Anthropocene Yet Unseen," Theorizing the Contemporary series edited by Cymene Howe and Anand Pandian, Cultural Anthropology website, June 28. https://culanth.org/fieldsights/1152-exposure.

Roberts, Elizabeth F. S., and Camilo Sanz

Forthcoming "Bioethnography: A How-To Guide for the Twenty-First Century." In The Palgrave Handbook of Biology and Society, edited by Maurizio Meloni, John Roush, Laura Cromby, Des Fitzgerald, and Stephanie Lloyd. New York: Palgrave Macmillan.

2014 "Santa Muerte, Protection, and Desamparo: A View from a Mexico City Altar." Latin American Research Review 49, special issue: 129-48. https://doi.org/ 10.1353/lar.2014.0064.

Rozental, Sandra

2016 "In the Wake of Mexican Patrimonio: Material Ecologies in San Miguel Coatlinchan.” Anthropology Quarterly 89, no. 1: 181-219. https://doi.org/ 10.1353/anq.2016.0007.

Sanabria, Emilia, and Emily Yates-Doerr

2015 "Alimentary Uncertainties: From Contested Evidence to Policy." BioSocieties 10, no. 2: 117-24. https://doi.org/10.1057/biosoc.2015.17.

Sassen, Saskia

2014 Expulsions: Brutality and Complexity in the Global Economy. Cambridge, Mass.: Harvard University Press.

Scheper-Hughes, Nancy

1992 Death Without Weeping: The Violence of Everyday Life in Brazil. Berkeley: University of California Press.

2001 Saints, Scholars, and Schizophrenics: Mental Illness in Rural Ireland. Berkeley: Shoshan, Nitzan University of California Press.

2015 “Las temporalidades de la crisis en Santa Fe, D.F.” Sociológica 30, no. 84: 9-38. Tosoni, Simone, with Trevor Pinch

2016 Entanglements: Conversations on the Human Traces of Science, Technology, and Sound. Cambridge, Mass.: MIT Press.

Winner, Langdon

1980 “Do Artifacts Have Politics?” Daedalus 109, no. 1: 121-36. http://www.jstor. org/stable/20024652.

Yates-Doerr, Emily

2012 "The Weight of the Self: Care and Compassion in Guatemalan Dietary Choices." Medical Anthropology Quarterly 26, no. 1: 136-58. https://doi.org/10.1111/j. 1548-1387.2011.01169.x. 